\title{
TRUMP VS JOKOWI: EXPLORING THE LEXICOGRAMMATICAL VARIATION OF HEAD OF STATES' TWITTER COMMUNICATION
}

\author{
Putu Nur Ayomi \\ Universitas Mahasaraswati Denpasar \\ email: putu.nur.a@unmas.ac.id
}

\begin{abstract}
Unlike other social media such as Facebook or Instagram, which is usually used to connect people and maintain relationships, Twitter focuses on information sharing. This makes Twitter an ideal platform to discuss ideas and generate conversations around particular issues. This article explores and compares the lexicogrammatical choices made by President Donald Trump and Joko Widodo in a selection of their tweets. Guided by Systemic Functional Linguistics (SFL), this article explains the stylistic differences and their implications in the three metafunctions: ideational, interpersonal, and textual, including the language used for evaluation drawn from the Appraisal system network. The study reveals that Trump's language is more spoken-like than that of Jokowi's. Trump also employs various appraisal strategies to negatively evaluate his opponents and counter various adverse accusations addressed to him. Jokowi, on the other hand, uses more abstract written-like language and use more positive appraisal strategies mainly addressed to his government programs and plans amid the Covid-19 pandemic. The result of the study reveals that different individual lexicogrammatical choices can generate diverse representations and images.
\end{abstract}

Keywords: lexicogrammar, metafunction, grammatical metaphor, appraisal

\section{TRUMP VS JOKOWI: MENDEDAH VARIASI LEKSIKOGRAMATIKAL KOMUNIKASI KEPALA NEGARA DI TWITTER}

\begin{abstract}
Abstrak
Berbeda dengan media sosial lain seperti Facebook atau Instagram yang biasanya digunakan untuk menghubungkan orang dan menjaga hubungan, Twitter berfokus pada berbagi informasi. Ini menjadikan Twitter platform yang ideal untuk mendiskusikan ide dan menghasilkan percakapan seputar masalah tertentu. Artikel ini membahas dan membandingkan pilihan leksikogramatikal dari Presiden Donald Trump dan Joko Widodo dalam kumpulan tweet mereka. Dengan panduan teori Linguistik Fungsional Sistemik, artikel ini menjelaskan perbedaan gaya bahasa kedua presiden dan implikasinya dalam ketiga metafungsi: Ideasional, Interpersonal, dan Tekstual, termasuk penggunaan bahasa sebagai sarana evaluasi yang diambil dari sistem Appraisal. Kajian ini mengungkapkan bahwa bahasa Trump lebih bercirikan bahasa lisan dibandingkan bahasa Jokowi. Trump juga menggunakan berbagai strategi Appraisal untuk mengevaluasi
\end{abstract}


lawan politiknya secara negatif dan untuk melawan berbagai tuduhan negatif yang ditujukan kepadanya. Di sisi lain, Jokowi menggunakan bahasa yang lebih abstrak dan bercirikan bahasa tertulis serta menggunakan strategi Appraisal positif terutama yang ditujukan pada program dan rencana kerja pemerintahannya di tengah pandemi Covid-19. Hasil penelitian menunjukkan bahwa pilihan leksikogramatikal individual yang berbeda dapat menghasilkan representasi dan citra yang beragam.

Kata kunci: leksikogramatika, metafungsi, metafora gramatikal, appraisal

\section{INTRODUCTION}

Success in politics is usually highly determined by the combinations of endorsement by party leaders and other prominent politicians, approval from influential interest groups or organizations, and the money to fund the campaign. These, however, are not only the case (Francia, 2018). In this era of democracy, people vote for their leaders directly, and consequently, politicians depend heavily on mass media to gain popularity and build positive images for the general public. Social media serves as a free platform for those involved in politics to communicate directly to the public. It provides alternatives to the news and narratives circulated by the mass media. Trump, for example credited his success in 2016's election to social media (Clarke \& Grieve, 2019). Trump's Twitter account provided billions of dollars' worth of free media campaign than the expensive commercial and campaigns used by his opponents, who raised more money to fund their campaign. The success came out shocking for many, including Trump's campaign team itself as it was considered as against "conventional wisdom" (Francia, 2018; Gelman \& Azari, 2017).
Unlike other social media such as Facebook or Instagram, which is usually used to connect people and maintain relationships, Twitter focuses on information sharing. This makes Twitter an ideal platform to discuss ideas and generate conversations around particular issues, making it an attractive source of news for journalists $C$ their media of communication, they also use Twitter as a medium for diplomacy between the head of states that resemble how they interact conventionally (Iakhnis \& Badawy, 2019). The growing importance of social media communication also requires more attention to be paid to the politician's linguistic strategy.

In terms of the stylistic of the heads of state's tweets, several studies have analyzed Trump's tweets. For example, Anderson (2017) found that among 100 Trump's tweets with the highest engagement (highest sum of likes and retweets) consist of issues surrounding policy, personal attack, self-praise, media criticism, and praising others. Ross \& Caldwell (2020) found that Trump mostly used the negativity strategies in his tweet, especially prior to the 2016's election, which emphasized the opponent's weaknesses and accountability. They 
analyzed how this strategy is delivered linguistically by using Appraisal analysis in the framework of SFL (Martin \& White, 2005), namely the negative evaluation in terms of Attitude, Engagement, and Graduation.

Although the studies mentioned above have discussed some linguistic aspects of President Trump's tweets, they are still partial, meaning that they only discussed several linguistic aspects. Besides that, it is also important to see the linguistic strategy used by other head of states. In this matter, this paper will compare how President Trump and Indonesian President, Joko Widodo, exploit linguistic resources to mean what they say on Twitter. America and Indonesia are among the countries with the highest Twitter users. This can provide us with a bigger picture of how different linguistic practices can produce different messages. Several studies have discussed Jokowi's language style in speeches from different perspectives such as of Critical Discourse Analysis (CDA) (Asmara, 2016) and semantic (Nurpadillah, 2017) and in Presidential debate (Setiana, Munaris \& Fuad, 2015). However, none have discussed Jokowi's language on Twitter which has different platform.

In order to get a comprehensive understanding on how the whole meanings are arranged in the presidential tweets' type of text, this study employs the theoretical framework from SFL (Halliday \& Hasan, 1985; Halliday \& Matthiessen, 2014). SFL is a functional theory of linguistic in which language is modeled and mapped based on the context of its use. Language simultaneously has three variables: Field, Tenor, and Mode. Field deals with the content of the message, Tenor is about the nature of the relationship between participants in communication and Mode concerns about how the message is delivered. These three contexts of situation generate meaning (metafunctions) that are realized by the lexicogrammar; the three metafunctions are respectively ideational, interpersonal, and textual. The ideational function which expresses experiences primarily deals with the Transitivity system (the arrangement of Process, Participant, and Circumstances) and the logical connection between those experiences. The interpersonal functions negotiate the nature of the relationship between those involved in communication which is realized by Mood system (declarative, interrogative, etc.) and Modality system. Lastly, the textual metafunction controls the arrangement of the information (the ideational and interpersonal meaning) within a stretch of clause through Theme and Rheme's configuration. Another addition to the discourse semantic in terms of interpersonal metafunction is Appraisal system, which is the language resource for evaluation that comprise of the attitude of the speaker, how the speaker scales the intensity of meaning and how the speaker engages other voices in his statements (Martin \& White, 2005).

\section{METHOD}

This study's data source is the latest 20 tweets from President Trumps and Jokowi, gathered on 29 July 2020. The data were analyzed qualitatively to look for the types of lexicogrammatical variations they used, based on the perspective of SFL 
described in the previous section. Some quantitative data will be also used to support the analysis. First, the data are classified based on the linguistic realization in each metafunction. Next, they will be discussed and explained, starting from the ideational, interpersonal, the textual metafunction and lastly the Appraisal system. Because of different political contexts and happening in America and Indonesia, some context of situations needs to be explained. The United States of America is in the period of the presidential election; therefore, the tweets' contents will also relate to this 2020's election. President Jokowi, however, is in the middle of his term of office. Most countries in the world today are highly affected by coronavirus pandemic. Heads of states are struggling to navigate their country to cope with this global economic, health, and general welfare turbulence.
The content of the tweets is not the major part of the analysis; however, as there is always an interplay between the language style and the content, especially on the purpose of the tweets, this will support the analysis as needed.

\section{RESULT AND DISCUSSION Result}

By analyzing the lexicogrammatical features of the two presidents' tweets in the three metafunctions, there are some characteristics of their language that can be found. These lexicogrammar characteristics are in the three areas of meanings; the ideational, interpersonal, and textual. However, before going on to the metafunctions, it is worth to note the average clause lengths and the text complexity of the presidents' tweet, which can be presented as follow:

Table 1 Text Length \& Complexities

\begin{tabular}{lll}
\hline \multicolumn{1}{c}{ Text Complexity } & \multicolumn{1}{c}{ Trump } & \multicolumn{1}{c}{ Jokowi } \\
\hline $\begin{array}{l}\text { Number of Words } \\
\text { Number of Clauses }\end{array}$ & 564 & 658 \\
$\begin{array}{l}\text { Number of dependent } \\
\text { Clause }\end{array}$ & 11 & 76 \\
$\begin{array}{l}\text { Number of Words per } \\
\text { Clause }\end{array}$ & 8,67 & 26 \\
$\begin{array}{l}\text { Logical Relation/ } \\
\text { Conjunction }\end{array}$ & $\begin{array}{l}\text { 13: } \\
\text { Consequences(4): so, if, even if } \\
\text { then } \\
\text { Addition (7):plus, and x5, other } \\
\text { than } \\
\text { Contradiction: 2 } \\
\text { actually, but }\end{array}$ & $\begin{array}{l}\text { Consequences 4: jadi 'so', apabila 'if', } \\
\text { untuk itu 'for that', agar (for) }\end{array}$ \\
& $\begin{array}{l}\text { 'including', misalnya (for example) } \\
\text { Time (3): sekarang 'now', sampai } \\
\text { 'until', setelah 'after' }\end{array}$ \\
& $\begin{array}{l}\text { Contradiction (4): bagaimanpun } \\
\text { 'however',, , meski'although',', ,kendati } \\
\text { demikian 'however', tentu saja 'of } \\
\text { course' }\end{array}$ \\
\hline
\end{tabular}


Ideational metafunction deals with how experiences are constructed in the language, which is grammatically realized by the configuration of participants, processes, and circumstances within clauses. This study highlights the use of process and participants' types which are the obligatory elements of clauses:

Table 2. The Proportion of Process Types

\begin{tabular}{ccc}
\hline Type of process & Trump & Jokowi \\
\hline Material & 20 & 34 \\
Relational & 23 & 21 \\
Mental & 6 & 7 \\
Verbal & 5 & 5 \\
Behavioral & 6 & 3 \\
Existensial & - & 3 \\
\hline
\end{tabular}

Table 3. Types of Participants

\begin{tabular}{lll}
\hline Participant & \multicolumn{1}{c}{ Trump } & \multicolumn{1}{c}{ Jokowi } \\
\hline Personal & I(x4),me, you & mereka \\
Pronoun & $(\mathrm{x} 2)$, he $(2)$, his & 'they'(x5), kita \\
& $(2)$, they & 'we' (x7), saya \\
& $(\mathrm{x} 10)$, them $(\mathrm{x} 2)$, & 'I' (x5), kami \\
& their, we (x8), & 'we', ku 'my', \\
& our (10) & His Majesty \\
Proper & Sleepy Joe Bidden & IMF, Bank \\
name & (x2), Sleepy Joe, & Dunia 'The \\
& Ronald Reagen, & World Bank', \\
& ANTIFA, Jerry, & OECD, Bapak \\
& Nadler, America, & Isdianto, \\
& Rusia (x3), & Gubernur \\
& Twitter, & Kepulauan \\
& Portland, Seattle, & Riau, Mesjid \\
& The Washington & Istiqlal, Istana \\
& Post, Amazon, & Bogor, Asia \\
& Homelands & Tenggara, \\
& Security, Federal & Indonesia, King \\
& Forces & Salman bin \\
& & Abdul Aziz \\
\hline
\end{tabular}

The striking difference between Trump texts and Jokowi's is their use of grammatical metaphor (GM), in which
Jokowi use much more Ideational GM as can be seen in the following table:

Table 4. Types and Number of Ideational GM

\begin{tabular}{lcc}
\hline \multicolumn{1}{c}{ Types of GM } & Trump & Jokowi \\
\hline Nominal GM & 9 & 38 \\
Verbal GM & 1 & 6 \\
Adjectival GM & 1 & 3 \\
Circumstantial GM & - & 1 \\
\hline
\end{tabular}

Within the scope of interpersonal metafunction, the use of Mood or speech function and Modality that enact speaker position and attitude toward the message are the point of the analysis presented in Table 4. Another linguistic resource that can be used to manage interpersonal meaning is by using the interpersonal GM of Mood and Modality instead of the congruent expressions. Both Trump and Jokowi used one interpersonal GM of Mood; however, only Jokowi used interpersonal GM of Modality.

Table 5. Types of Mood \& Modality

\begin{tabular}{|c|c|c|}
\hline $\begin{array}{l}\text { Mood } \\
\text { System }\end{array}$ & Trump & Jokowi \\
\hline $\begin{array}{l}\text { Indicative- } \\
\text { Declarative: }\end{array}$ & $\begin{array}{l}46 \text { (with } 7 \\
\text { exclamative } \\
\text { declarative) }\end{array}$ & 66 \\
\hline $\begin{array}{l}\text { Indicative- } \\
\text { Interogative }\end{array}$ & 1 & - \\
\hline $\begin{array}{l}\text { Imperative- } \\
\text { Command }\end{array}$ & 4 & 5 \\
\hline Other (offer) & - & 2 \\
\hline $\begin{array}{l}\text { Minor } \\
\text { Clauses } \\
\end{array}$ & 5 (exclamation, & 3 (Congratulation) \\
\hline Modality & & \\
\hline Modalization & would (5) & akan 'would' (x2) \\
\hline Modulation & should & $\begin{array}{l}\text { harus 'must' ( } x 5) \text {, } \\
\text { mesti 'must' }\end{array}$ \\
\hline
\end{tabular}

Textual metafunction deals with how the two presidents manage information in their tweets, and one interesting point 
is about how they manage the Theme or point of departure of the message. Trump and Jokowi used them differently, which is illustrated in Table 8.

Table 6. Number and Types of Theme

\begin{tabular}{lcc}
\hline Types of Theme & Trump & Jokowi \\
\hline Marked Topical There & 1 & 15 \\
Interpersonal Theme & - & 7 \\
& & \\
Textual Theme & 7 & 9 \\
\hline
\end{tabular}

Another system that can show how both heads of states express their approvals or disapprovals for ideas, things, or people is the Appraisal system that works within interpersonal metafunction. These comprise three interrelating areas, which are Attitude, Engagement, and Graduation. The linguistic resources used by both presidents can be seen in Table 7, 8 and 9 as follow:

Table 7. Trump and Jokowi Expressions of Attitude

\begin{tabular}{|c|c|c|}
\hline Attitude & Trump & Jokowi \\
\hline \multicolumn{3}{|c|}{ Affect (expression of emotions) } \\
\hline \multirow[t]{3}{*}{ Positive } & - & (3) \\
\hline & & sabar 'patient', bergembira 'happy', \\
\hline & & semangat 'enthusiastic' \\
\hline \multirow[t]{2}{*}{ Negative } & $(4)$ & - \\
\hline & not happy (2), hate, disgusting & \\
\hline \multicolumn{3}{|c|}{ Judgement (evaluation of people and their behavior) } \\
\hline \multirow[t]{2}{*}{ Positive } & (8) & (5) \\
\hline & $\begin{array}{l}\text { very smart, witty, wonderful, sweet, talented, } \\
\text { innocent, great man, great }\end{array}$ & $\begin{array}{l}\text { peduli 'care', kreatif 'creative', , sehati } \\
\text { 'healthy', pemenang 'winner', tak henti } \\
\text { berinovasi 'costantly innovating' }\end{array}$ \\
\hline \multirow[t]{5}{*}{ Negative } & $(24)$ & - \\
\hline & crazy, lie, violence (x2), anarchist ( $x 4)$, illegal & \\
\hline & (x2), unfair, deraged, agitators (x2), sleepy (3), & \\
\hline & puppet of the left, protestors, vandalize, & \\
\hline & $\begin{array}{l}\text { damage, discredit, nice (sarcastic), where is } \\
\text { justice }\end{array}$ & \\
\hline \multicolumn{3}{|c|}{ Appreciation (evaluation of things) } \\
\hline \multirow[t]{2}{*}{ Positive } & (5) & (5) \\
\hline & great (x2), successful, great going, golden age & $\begin{array}{l}\text { efektif 'effective', jelas 'clear', megah } \\
\text { 'majestic',berhasil 'successful', agresif } \\
\text { 'aggressive' }\end{array}$ \\
\hline \multirow[t]{3}{*}{ Negative } & $(14)$ & (4) \\
\hline & nasty, not good, never a good, bow up, bad, & minus (x2) \\
\hline & $\begin{array}{l}\text { fake (x2), destroy, crash, burn, suffer, wrong, } \\
\text { worse, scam }\end{array}$ & $\begin{array}{l}\text { ketidakpastian 'uncertainty', tidak bebas } \\
\text { 'unfree' }\end{array}$ \\
\hline
\end{tabular}


The Appraisal system of Engagement deals with how the writer manages his voice and other's perspective in the text. In more heterogloss texts that allow other's voices in the text besides the writer's voice, the writer can expand the engagement by acknowledging others' perspectives. He or she can also contract the space by rebutting or restrict alternative perspectives. Table 8 shows several linguistic resources for managing engagement used by both presidents.

Table 8. Trump and Jokowi Expressions of Engagement

\begin{tabular}{lll}
\hline $\begin{array}{l}\text { Engagement } \\
\text { (Heterogloss) }\end{array}$ & Trump & Jokowi \\
\hline Expanding & & \\
\hline Modality & - & apabila berhasil \\
& 'if successful' \\
Attribution or & memprediksi \\
acknowledge & 'predict', prediksi \\
& 'prediction' \\
& menyampaikan \\
& 'states', bilang \\
& 'said', \\
& diperkirakan \\
& 'predicted', opini \\
& 'opinion \\
\hline
\end{tabular}

\begin{tabular}{|c|c|c|}
\hline $\begin{array}{l}\text { Engagement } \\
\text { (Heterogloss) }\end{array}$ & Trump & Jokowi \\
\hline Distance & $\begin{array}{l}\text { potray, call, } \\
\text { say }\end{array}$ & \\
\hline \multicolumn{3}{|l|}{ Contracting } \\
\hline Negatives & $\begin{array}{l}\text { not (x3), no, } \\
\text { don't }(x 2)\end{array}$ & \\
\hline Countering & $\begin{array}{l}\text { actually (x2), } \\
\text { but (x2), } \\
\text { still, just } \\
(x 3) \text {, so, only }\end{array}$ & $\begin{array}{l}\text { bagaimanapun } \\
\text { 'however', meski } \\
\text { 'although', } \\
\text { kendati demikian } \\
\text { 'nevertheless' }\end{array}$ \\
\hline \multicolumn{3}{|l|}{ Proclaim } \\
\hline Continuatives & plus & $\begin{array}{l}\text { tetap (x2) 'keep', } \\
\text { sama 'the same' }\end{array}$ \\
\hline $\begin{array}{l}\text { rhetorical } \\
\text { questions }\end{array}$ & $\begin{array}{l}\text { Where is } \\
\text { JUSTICE? }\end{array}$ & - \\
\hline
\end{tabular}

Another resource of evaluation is Graduation system by which writers can increase or decrease the intensity of evaluation to a phenomenon. Both Trump and Jokowi use adverbial and adjectival graders to amplify or reduce the intensity of the phenomena both on positive and negative evaluation, as can be seen in Table 9.

Table 9. Trump and Jokowi Uses of Graduations

\begin{tabular}{lll}
\hline Graduation & Trump & Jokowi \\
\hline Adverbial \& Adjectival & $(4)$ & $(6)$ \\
Graders (Up) & great (x2), very, better than ever & serendah-rendahnya 'as low as \\
& possible', setinggi-tingginya 'as \\
& high as possible', massif \\
& 'massive', agresif 'aggressive', \\
& luar biasa 'extraordinary', besar- \\
& besaran 'massive'
\end{tabular}

Adverbial \& Adjectival Graders (Down) just, at least, whatever
(2)

lumayan 'enough', tetap 'still' 


\begin{tabular}{lll}
\hline Graduation & Trump & Jokowi \\
\hline Use of Uppercase & 6 & - \\
& LAW \& ORDER, CRAZY, MAKE & \\
& AMERICA GREAT AGAIN, & \\
& EVERYONE, JUSTICE, & \\
& MINIMUM TEN YEARS IN & \\
& PRISON & \\
Repetition & 1 & \\
& Rusia, Rusia, Rusia! & \\
Exclamation or Swearing & 13 & $(3)$ \\
Capitalized Word's Initial & 18 & bersolek 'adorned' motor \\
Positive Core Meaning & $(1)$ & penggerak 'generator', \\
Graded Up & golden age & digaungkan 'echoed' \\
& & \\
Negative Core Meaning & $(6)$ & nasty, destroy, crash, burn, miles of \\
Graded Up & tape, deranged & \\
&
\end{tabular}

\section{Discussion}

\section{Text Length and Complexity}

Seeing from the length of both Trump's and Jokowi's Tweets, as illustrated in Table 1, Jokowi's Tweets are relatively longer for about $16 \%$ as compared to Trump's tweets. However, if the number of words per clauses is counted, they appear only slightly different. There are yet notable differences in terms of the number of the dependent clause or subordinate clauses. Jokowi used considerably more clauses with hypotactic relation, resulting in more grammatical complexity. On the other hand, Trump used more embedded clauses that modify nouns, which are participants either in the main clauses or in the dependent clauses. These can be seen in the example below:

(1) ///Anarchists, Agitators or Protestors [[who vandalize or damage our Federal Courthouse in Portland, or any
Federal Buildings in any of our Cities or States]], will be prosecuted under our recently re-enacted Statues \& Monuments Act//. (TT)

(2) ///Meski kita tengah disibukkan dengan penanganan pandemi Covid-19, //saya tetap menginstruksikan //agar layanan diagnostik maupun pengobatan terhadap pasien tuberkulosis harus tetap berlangsung. ///.(JT)

'// Although we are made busy dealing with Covid-19,// I still instruct // that the diagnostic and treatment services for the tuberculosis patient must continue.///,

In sentence one which is taken from Trump's tweet, the clause who vandalize or damage our Federal Courthouse in Portland, or any Federal Buildings in any of our Cities or States, is a relative clause that characterizes the things which in this case are the anarchist, agitators, and 
protestors. Syntactically it belongs to the scope of the nominal group. It does not tell about another going on unfolded through time as that carried out by subordinate clauses. Sentence 2, which is taken from Jokowi's tweets, consists of two subordinate clauses. The first one Although we are made busy dealing with Covid-19 expands the main clause, I still instruct by embellishing it with some circumstantial context, which in this case is about the contradictory situation that happens to lead to what stated in the main clause. The second dependent clause that the diagnostic and treatment services for the tuberculosis patient must continue, which is the projected clause, is the wording of what Jokowi instructs, or say. All three clauses are three separate situations connected syntactically through the system of logico-semantic relation.

Although not always lexically realized, the logico-semantic relations are explicitly expressed by the use of a conjunction. Both presidents also used similar types of conjunction except for the temporal ones. The differences are caused mainly by the messages both Presidents wanted to get across. Jokowi, for example, used more temporal conjunctions such as sekarang 'now', sampai 'until', setelah 'after' to explain the steps taken by the government to handle the pandemic (as in sentence 3). As illustrated in sentence 2 , the contrastive conjunction meski although is used to highlight the contrast between the negative situation caused by the pandemic and the positive steps that the government has taken or will take. The conjunction of cause and effect also shows the same relation while maintaining a more neutral view of the consequence relation. On the other hand, as illustrated in excerpt 4, Trump used conditional-consequences conjunctions if and even if together with the contradictory conjunctions but and actually to predict what will happen if his opponent wins and how the opposing media will react to his policy. By giving a negative forecast about his opponents, Trumps made himself more favorable to be voted. He also prepared his audiences to the negative comments that are expected to come. This is also supported by other evaluation resources to be explained in Appraisal subsection.

(3) Penanganan kesehatan tetap prioritas, aura krisis kesehatan digaungkan, sampai vaksin tersedia dan digunakan secara efektif.

'Health care remains a priority, the aura of a health crisis is echoed, until vaccines are available and used effectively'

(4)FakeNews@CNN sayswe should do more testing. But even if we did 100 times more they would then say it is still not enough.

\section{Ideational Metafunction: Process, Participants}

Both Trump and Jokowi mostly used material and relational processes in the tweets. Material process (realizing doing and happening) is the most dominant type of process in many types of texts in many languages. It is not surprising that they also dominate the tweets by both presidents. The relational process that identifies and characterizes participants also play a major role in both tweets. In 
English, this process is usually realized by an auxiliary verb. In the Indonesian language, they are frequently ellipted, especially in intensive attributive type, the insertion of verb sometimes created a highly formal written type of text (Ayomi, 2018). The ellipted type frequently occurs in Jokowi's tweet, as can be seen in excerpt 5. The mental, verbal and behavioral and process are not very frequent, Trump hardly used existential process in his tweets, and Jokowi used them three times by the use of verb ada 'exist' to inform the reader of some occurrences of phenomena.

The participants in the tweets of both presidents vary according to the content of the message. As illustrated in table 4, both President use the first person pronoun quite frequently, Trump used $I$ four times and me once while Jokowi used saya ' $I$ ' and the possessive $k u$ ' $m y$ ' seven times. By putting themselves as participants in the clause, they speak as an individual instead of as an institution. For example, Trump mentioned What I have done will lead to a $50 \%$ reduction in prices, or I was only President in 51 years that got a Prescription D reduction!. Jokowi do the same, such as Saya menginstruksikan 'I instruct', Saya meminta 'I ask' (twice), Saya mengharapkan 'I hope', and Saya kembali bertemu 'I meet again'. Both presidents put the agency on themselves as the person in charge. In Trump's case this is related with the verb of doing (done, got) and in the case of President Jokowi the processes are mostly of verbal (instruct, ask) or mental (hope). In President Jokowi's case, most of his tweets are usually followed by a photo depicting the activity he attended. By doing so, both presidents asserted their authority and promoted themselves. Jokowi also employed exclusive firstperson singular kami 'we' twice when talked about him and his wife.

The frequency of the first-person plural and third-person plural occurrences are also quite similar in both presidents' text, although they differ in use. Jokowi use of they is more inclusive in which it refers to the target group of the government program, such as Indonesian children and low-income citizen and micro industries. However, many uses of they in Trump's tweets are in opposition to ' $w e$ ' in which they refer mostly to his opponents, media, his critics, and Portland protesters. Trump also used second-person pronouns he and his to refer to several persons, mostly his political opponents such as Joe Biden or Jerry, Nadler. This does not occur in Jokowi tweet. Indonesian usually avoids using general dia 'he/she,'especially in adult formal conversation and replace it with honorific Beliau or Bapak 'Mr' or Ibus Mrs' followed by a proper name. Trump also used you twice to address the reader directly. There is no use of the second-person pronoun in Jokowis tweets. The use of pronouns is quite delicate in the Indonesian language. There are several choices to make to show a certain degree of respect and closeness especially in the use of a direct second-person pronoun (see Kridalaksana, 1982). In many contexts the use of kita 'exclusive we' is preferred rather than you. 


\section{Ideational Grammatical Metaphor}

As illustrated in table 4, Jokowi employs four times more GM than Trump. One of the characteristics of adult and written language, especially the language valued in an academic setting, is the GM, especially the ideational metaphor (Halliday \& Matthiessen, 1999; Liardét, 2016; Liardét \& Black, 2020). Explained simply, GM is construing the meaning of one grammatical unit with another grammatical unit. GM allows the higher rank unit, e.g., the information in a clause is packed into a nominal group, which enables more information to be realized within a minimum grammatical unit. We can observe this from excerpt 5 and its congruence reconstruction, excerpt 5' below:

(5) The only reason they are going all out is the massive PRICE REDUCTIONS you are getting (TT)

(5') They are going all out only because you are getting the low price after they have to reduce the price massively

Sentence 5 above is in the form of a simple clause, while the congruent form (sentence 5') is a complex hypotactic clause consisting of three clauses. There are several shifts caused by GM that can be observed in the excerpt: the shift from conjunction to thing/noun (because -reason), the shift from process/verb to thing/noun (reduce-reduction), the shift from circumstance/adverb to quality of thing/adjective (massively-massive) and the shift from thing/noun to modifier (reduce the price-price reduction).

Besides the nominal and adjectival GM that can be seen in the example above, both presidents used verbal GM. Trump and Jokowi used conjunctionprocess/verb GM once each: (because-lead to) and (because- menimbulkan 'create), in which causal relations congruently realized by conjunctions are constructed as the verb of the main clause. Verbal GM is usually the syndrome following a clause nominalization in clause complex. One interesting thing is the five times use of Process-Range/Medium GM syndromes by president Jokowi: perawatan pasien Covid-19 dilakukan 'the treatment of Covid-191 patients was carried out' mengikuti pemeriksaan kesehatan 'followed a health check, melaksanakan uji klinis pengobatan 'conducted clinical trials, pengobatan terhadap pasien tuberkulosis harus tetap berlangsung , the treatment of tuberculosis patients must continue and mencapai eliminasi tuberkulosis 'achieve the elimination of tuberculosis. The syndrome is caused by the nominalization of processes, e.g. : merawat pasien Covid 19 'treat the Covid-191 patients' becomes perawatan pasien Covid 19 'the treatment of Covid-191 patients'. Later, the noun become the Range of the clause. Hollow generic verbs (with no congruent form), e.g. melakukan/dilakukan 'do/was done' later fills in the Process slot of the clause. Other generic verbs usually occurring in the syndromes are mengadakan 'carry out', melaksanakan 'conduct', berlangsung 'happen' or mengikuti' join', etc. This GM syndrome is ubiquitous in formal Indonesian language and academic 
writing (Ayomi, Dreyfus, Hadi \& Sutrisno, 2020).

The use of GM in texts creates more static, abstract, and technicalized text. In this sense, Jokowi tweets sound more formal, written-like, and academic than Trump tweets. However, the claim made in this study should be seen from a stylistic point of view; that particular choice of linguistic form can create specific effects. The high use of GM tends to create a more abstract and dense information text which requires more trained readership. Thus, whether or not the text is effective and acceptable to the readers requires another study. Besides that, some particular unfavorable discoursal effects of nominalization, e.g., the omission of responsible agent and information concealment (Fairclough, 2003), are often criticized in critical discourse analysis.

\section{Mood and Modality}

As illustrated in Table 5, in terms of their speech role in the texts, both Jokowi and Trump mostly used Indicativedeclarative Mood in which the writer provides information to the readers. However, Trump inserted exclamative mark (!) in seven of them without modifying the structure of the declarative Mood. This adds to the tone and emotion expressed instead of the usual form and will be discussed further in the evaluative function of language. Although Twitter provides a platform for dialog in the comment and reply function, the dialogic, two-way communication is not presented, especially if it is seen from the lack of interrogatives. Trump employed one interrogative, Where is JUSTICE?
Nevertheless, it is a rhetorical question that informs the reader about the lack of justice instead of seeking information. There is also an act of exchanging service in the tweets in which both presidents used imperatives. For example, Trump demands the reader to do certain things for him, such as Don't do it!, Vote these people out, Buy it now!. Jokowi however, use a more persuasive language by using interjunction Ayo 'lets's' that invite the readers to do things instead of command them, Ayo, jaga imunitas tubuh dengan berolahraga rutin, selalu memakai masker, rajin mencuci tangan, dan jaga jarak 'Come, keep your body immunity by exercising regularly, always wearing a mask, washing your hands diligently, and keeping social distance'. He also used downtoner tetap 'stay/keep' to ask his people to take care of themselves during the pandemic such as Tetap semangat belajar dari rumah, tetap sehat, dan bergembira. 'Keep the spirit of learning from home, stay healthy, and happy.

In communication, it is also essential to acknowledge the Modality, which deals with the intermediate degrees between the Yes and No polarity. In proposition, where information is being exchanged, the intermediate polarity is about probability and usuality (Modalisation). When it comes to the proposal where the good and services are being exchanged the intermediate polarity is about the degree of obligation and degrees of inclination (Modulation) (Halliday \& Matthiessen, 2014: 147). In his tweets, Trump used more modality markers than Jokowi. Both used the modal would that expresses prediction of what will happen in a certain condition such as in Jokowi's IMF memprediksi 
pertumbuhan ekonomi global akan minus 2,5\% 'The IMF predicts that the global economic growth will be minus 2.5\%' or in an imagined situation such as in Trump's If Sleepy Joe Biden, the puppet of the Left, ever won. Markets would crash, and cities would burn. In terms of the use of Modulation, both presidents only employed the modal should and must that assert obligation that the participants must do. However, mostly, they did not use them to impose the obligation to the reader such as in Jokowi's Postur APBN tahun 2021 harus dirancang untuk mengantisipasi berbagai kemungkinan 'The posture of the 2021 APBN must be designed to anticipate various possibilities' but to tell the reader what the government must do under certain circumstances or if they do, the participant is exclusive firstperson plural we that make it as an invitation to do something such as Kita harus menyikapinya dengan bekerja luar biasa dalam konteks manajemen krisis. 'We must respond it by doing extraordinary works in the context of crisis management.'

\section{Interpersonal GM}

As illustrated in Table 6, both heads of states also utilized interpersonal GM. Trump's tweet, Where is JUSTICE?, is a rhetorical question in which the indicative declarative meaning 'This is injustice.' is construed as interrogatives. By doing so, Trump lessens the imposition of his evaluation in responding to how the media treated him. Jokowi, on the other hand, used one metaphor of Mood and Modality. Jokowi used indicativedeclarative clause in the form of a projecting clause to realize an imperative, Untuk itu saya meminta agar pengujian pengujian, penelusuran, dan perawatan pasien Covid-19 dilakukan secara masif dan lebih agresif 'For that, I ask that the testing, tracking, and treatment of Covid-19 patients to be done massively and aggressively'. Using the projected verbal clause saya meminta.. 'I ask..' the speaker as the source of authority can be explicitly mentioned instead of by using the congruent imperative sentence. It also adds more politeness by using the verb ask and making the command as the content of saying.

Jokowi also used one metaphor of Modality to express his proposition, as a possibility is expressed by projecting mental clause diperkirakan is predicted' instead of using modal adjuct such as may or probably. This use of mental projecting clause adds more objectivity and explicit orientation to what is stated. The information sound more objective as it is made as if it is not solely from the speaker, and the source of information can be made more explicit. Manipulation, however, can occur, since by using the passive sentence, the source of information can be unmentioned, and the responsibility of the proposition lies nowhere.

\section{Textual Metafunction : Theme Arrangement}

It can be seen that Jokowi used more marked topical Theme and also textual and interpersonal Theme as clause's Theme, as compared to Trump. In terms of marked topical Theme, Jokowi often placed Circumstances as Theme of the massage, while Trump did it only once. By doing this, he highlighted the circumstantial context of the message, e.g., Setelah 42 tahun berdiri, Masjid Istiqlal 
kini bersolek lebih megah. 'After 42 years after its establishment, Istiqlal Mosque is now decorated more magnificently' in which after 42 years after its establishment introduces the proposition, creating a suspend rather than by using an unmarked topical Theme, in which the Subject becomes the Theme and Circumstance is placed in the Rheme position. Jokowi also used eight interpersonal Themes in the beginning of the sentence such as Alhamdulillah, Ayo 'Let' s', May, diperkirakan 'it is predicted', saya harapkan 'I hope', semoga 'may', and tentu saja 'of course' that introduce his interpersonal role and evaluation on the proposition in the beginning of sentences. The similarities in Theme use lies in how they employed textual Theme. Both used almost the same number of textual Theme that makes more explicit the relation between sentences. Trump used textual Themes such as so, plus, actually, but, if and just like, while Jokowi used the textual Themes such as untuk itu 'for that', di antaranya 'among others', sekarang ini 'now', apabila 'if', meski 'although', jadi 'so', and kendati demikian 'despite that'. Seeing from how they manipulate Theme position in their sentences, Jokowi shows more variety and dynamic instead of Trump.

\section{The Appraisal System of Attitude}

The expression of Attitude comprises three areas. The first is expressing the speaker or other people's feelings, e.g., Trump used the verb hate and strong negative adjective disgusting to show how he feels about something, e.g., So disgusting to watch Twitter's so-called "Trending". Jokowi, on the other hand, used more positive expressions of affect such as sabar 'patient', bergembira 'happy', semangat 'enthusiastic', not the to express his feeling but to ask his people to feel that way in this time of the pandemic. While both presidents showed their positive judgment toward a person or people's behavior, Trumps expressed 24 negative judgments through various lexical classes and units, especially about moral credibility and social sanction to his political opponents, media, and protestors. For example, his opponents were called puppet of the left and agitators while the protestors in Portland were called anarchist who did bad things such as vandalize and damage. In showing appreciation toward a particular object, phenomena, and appearances, both President used positive and negative forms of appreciation. However, Trump's negative evaluation highly exceeds Jokowi, which only addressed the negative evaluation of the country's economic situation. At the same time, Trump used 14 negative appreciation (as can be seen in Table 7) about the news and how the situation would be if Biden ever won the election, and some systems that he considered were disadvantages for him.

\section{The Appraisal System of Engagement}

As illustrated in Table 8, it is visible that Jokowi used more resources to expand the space, allowing other perspectives to be voiced in his tweets. He attributed the information from other sources through verbal or mental projected clauses, e.g., Sebulan kemudian, Bank Dunia menyampaikan, pertumbuhannya minus 5\%. 'A month later, the World Bank said, the growth was minus 5\%', or by using the 
noun prediksi 'prediction' and opini 'opinion'. Trumps also expanded space in his tweets; not to acknowledge but to create distance between what other said and what he considered was actually going on, e.g., Homeland Security or Federal Forces are little involved in Seattle, other than we have a large standby team in case of emergency. The media is calling that one wrong also. In contrast, Trump contracted spaces of other perspectives significantly more frequently than Jokowi by the use of negators, countering conjunctions, and by proclaiming the truth of his perspective utilizing continuatives and rhetorical questions. From how both Presidents managed engagement resources, it can be seen from the data that the purpose of Jokowi tweet is to inform and Trump to counter the negative opinions about his government.

\section{The Appraisal System of Graduation}

Other key differences are that Trump utilized more numbers and a lot more variety of graders. Trumps used exclamation marks (!) thirteen times in declarative sentences. For example, The ad is a lie!, by doing so, he increased the tone of his statement depending on the content of the message. In the example above, it showed a more resentful manner and can be read in rising intonation. Trump also used capitalized initial letter to highlight important words that are not supposed to be capitalized, such as for the word Virus, Trending, Anarchist, etc. Another characteristic of Trump's tweet is his use of uppercases for certain words, as shown in Table 9. This makes the massage "bigger and louder" and creates a rising intonation as in spoken language.
He also used repetition with an exclamation mark Jerry, blame it on Russia, Russia, Russia!, which made his tweet highly informal and spoken-like. Additionally, Trump also used more exaggerated and hyperbolic words that amplify negative meaning, such as if Sleepy Joe Biden, the puppet of the Left, ever won. Markets would crash, and cities would burn. Our Country would suffer like never before.

\section{CONCLUSIONS}

This paper has discussed the various lexicogrammatical variations that President Trump and Jokowi used in their tweets. Apart from the contents of the message they conveyed, Jokowi used more formal and academic language especially in terms of the Ideational grammatical metaphors, hypothetic clause complexes, various variations of Themes and marked Themes and the imperative mode of invitation. A significant difference lies in the use of the Appraissal resource. This article confirms that Trump expressed much negative evaluation in his tweets. It is different when compared to Jokowi, that inclined to give more positive assessments. When viewed from how Trump regulated various voices in his tweets, Trump often made contractions or restrictions, especially by refuting negative opinions from the media and his political opponents. In terms of how the two Presidents used the language resource of graduation, it can be seen that Trump used various graduation styles to intensify his message, especially to show negativity. This makes his tweet more spoken-like and loud. Although this study does not 
cover how the presidents' tweets can effectively gain public sympathy and support, it can be seen how the various lexicogramatical choices can generate individual language styles and images in social media.

\section{ACKNOWLEDGEMENTS}

I am very grateful for the PKPI scholarship, sandwich-like Program 2019, from the Indonesian Directorate General of Higher Education, which has allowed me to deepen my study of Systemic Functional Linguistics for three months at the University of Wollongong, Australia.

\section{REFERENCES}

Anderson, B. (2017). Tweeter-in-Chief: A Content Analysis of President Trump's Tweeting Habits. Elon Journal of Undergraduate Research in Communications, 8(2), 36-47. https://www.elon.edu/u/ academics / communications / journal/wp-content/uploads/ sites/153/2017/12/04_ TwitterInChief_Anderson.pdf.

Asmara, R. (2016). Strategi Kebahasaan Presiden Jokowi dalam Menanamkan Ideologi dan Manifesto Pemerintahan. Litera Jurnal Penelitian Bahasa Sastra dan Pengajarannya, 15(2), 379-388. https://doi.org/10.21831/1tr. v15i2.11836

Ayomi, P. N. (2018). Proses Relasional dan Konstruksinya dalam klausa bahasa Indonesia. Struktural Seminar' Universitas Dian Nuswantoro, 114124. DOI: $10.33810 / 274167$

Ayomi, P. N., Dreyfus, S., Hadi, S., \&
Sutrisno, A. (2020). The Research is Conducted...': An Exploration of a Grammatical Metaphor Syndrome in Indonesian Research Articles. Lingua Cultura, 14(1). DOI: https:// doi.org/10.21512/lc.v14i1.6342.

Clarke, I., \& Grieve, J. (2019). Stylistic variation on the Donald Trump Twitter account: A linguistic analysis of tweets posted between 2009 and 2018. PLOS ONE, 14(9), e0222062. https://doi.org/10.1371/journal. pone. 0222062 .

Fairclough, N. (2003). Analyzing Discourse. Routledge.

Francia, P. L. (2018). Free Media and Twitter in the 2016 Presidential Election. Social Science Computer Review, 36(4), 440-455. https://doi. org/10.1177/0894439317730302.

Gelman, A., \& Azari, J. (2017). 19 Things We Learned from the 2016 Election. Statistics and Public Policy, 4(1), 1-10. https://doi.org/10.1080/233044 3X.2017.1356775.

Halliday, M. A. K., \& Hasan, R. (1985). Language, Context and Text: Aspects of Language in A Social Semiotic Persperctive. Deakin University Press. Halliday, M. A. K., \& Matthiessen, C. M. I. (1999). Construing experience through meaning: a language-Based Approach to Cognition. Cassell.

Halliday, M. A. K., \& Matthiessen, C. M. I. (2014). An introduction to functional grammar (4th ed.). Edward Arnold.

Iakhnis, E., \& Badawy, A. (2019). Networks of Power: Analyzing World Leaders Interactions on Social Media. http://arxiv.org/abs/1907.11283. 
Kridalaksana, Harimurti. (1982). Dinamika Tutur Sapa dalam Bahasa Indonesia. In Hamurti Kridalaksana \& A. M. Moeliono (Eds.), Pelangi Bahasa. Bhratara Karya Aksara.

Liardét, C. L. (2016). Grammatical metaphor: Distinguishing success. Journal of English for Academic Purposes, 22, 109-118. https://doi. org/10.1016/j.jeap.2016.01.009.

Liardét, C. L., \& Black, S. (2020). Trump vs. Trudeau: Exploring the power of grammatical metaphor for academic communication. Journal of English for Academic Purposes, 45, 100843. https://doi.org/10.1016/j. jeap.2020.100843.

Nurpadillah, V. (2017). Wacana Kepemimpinan: Analisis Makna Konotasi dalam Teks Pidato Perdana Presiden Jokowi. Jalabahasa, 13(1), 83-92. DOI: https://doi. org/10.36567/jalabahasa.v13i1.43.
Ross, A. S., \& Caldwell, D. (2020). 'Going negative': An APPRAISAL analysis of the rhetoric of Donald Trump on Twitter. Language \& Communication, 70, 13-27. https:// d o i.org / 10 . $1016 / \mathrm{j}$. langcom.2019.09.003.

Setiana, A., Munaris, \& Fuad, M. (2015). Aspek Kebahasaan Jokowi pada debat Calon Presiden dan Kegunaannnya dalam Pembelajaran. Jurnal Kata (Bahasa, Sastra Dan Pembelajarannya, 3(3), 1-12. http:// jurnal.fkip.unila.ac.id/index.php/ BINDO1/article/view/8238/5190.

Verweij, P. (2012). Twitter Links between Politicians and Journalists. Journalism Practice, 6(5-6), 680-691. https://doi.org/10.1080/17512786. 2012.667272 . 